International Research Journal of Management, IT \& Social Sciences
Available online at https://sloap.org/journals/index.php/irjmis/
Vol. 5 No. 4, July 2018, pages: $1 \sim 17$
ISSN: 2395-7492
https://sloap.org/journals/index.php/irjmis/article/view/238

\title{
Assessment of Research Faculty Development Program Efficacy in Writing Research Proposals
}

\author{
Melanie G. Gurat ${ }^{a}$ \\ Fe Yolanda G. del Rosario ${ }^{b}$ \\ Pia L. Dizon ${ }^{c}$ \\ Marlon U. Saludarez ${ }^{\mathrm{d}}$
}

\section{Article history:}

Received: 10 January 2018

Revised: 25 May 2018

Approved: 10 June 2018

Published: 19 June 2018

\section{Keywords:}

Evaluation;

Effectiveness;

Performance;

Research Exposure;

Objectives Attainment;

\begin{abstract}
The dearth in research in Philippine higher education institutions (HEIs) had driven the Commission on Higher Education (CHED) to provide policies and mandates that are largely geared towards the improvement of research productivity. Saint Mary's University responded through Faculty Research Development Program, a scheme borne of the plans of the University Research Center (IDP Year 2013-2014) that aims to strengthen and enhance the research skills of faculty members. This study aimed to assess the efficacy of the research faculty development program workshop in writing full-blown research proposals. It involved the quantitative type of research using the posttest-only control group experimental design since the subjects were evaluated after the intervention. Evaluative in nature, it was conducted at Saint Mary's University, located at Bayombong, Nueva Vizcaya in Cagayan Valley. There were 25 subjects of the study who were all participants in the seminarworkshop. Researcher-made questionnaires and evaluated research proposals were the primary sources of the data in the study. Findings revealed that the research faculty development program workshop on writing research proposals was efficient. Hence, faculty members are highly recommended to continue participating in research capability training to become part of the tri-fold function of the university - the instruction, community extension, and research.
\end{abstract}

2395-7492@ Copyright 2018. The Author. This is an open-access article under the CC BY-SA license (https://creativecommons.org/licenses/by-sa/4.0/) All rights reserved.

\section{Author correspondence:}

Melanie G. Gurat,

University Research Center

Saint Mary's University, Bayombong, Nueva Vizcaya, Philippines,

Email address: melanie.gurat@yahoo.com

\footnotetext{
a Saint Mary's University, Bayombong, Nueva Vizcaya, Philippines

b Saint Mary's University, Bayombong, Nueva Vizcaya, Philippines

c Saint Mary's University, Bayombong, Nueva Vizcaya, Philippines

${ }^{\mathrm{d}}$ Nueva Vizcaya State University, Bayombong, Nueva Vizcaya, Philippines
} 


\section{Introduction}

Instructional process is aimed at accomplishing desired learning outcomes, but sometimes teachers may fail to achieve said instructional objectives. In some instances, they attempt to find out reasons that get in the way of achieving the instructional goals. The reasons may emanate from the curriculum, student or teacher behavior. In order to improve their classroom practices for initiating desired to learn outcomes, teachers often ponder why expected outcomes are not achieved, what could be the impediments that caused the non- accomplishment of learning outcomes, how to improve instruction for better learning and so on (Undurthy \& Peri, n.d.). According to them, one of the major reasons for such situation may be due to the gap between what teachers planned to do and what was done in the actual classroom instruction. Teachers are expected to identify these gaps between their thought and action. Consequently, they should attempt to mitigate this gap to improve quality of instruction. Accordingly, teachers need to play the role of a researcher; thus, teacher preparation programs should equip teachers with necessary skills in conducting classroom research. As this helps teachers in improving their classroom practices, teacher educators have to equip the teachers with the skills of conducting classroom research (Undurthy \& Peri, n.d.). However, a large number of instructors/professors do not find interest in doing research since their priority is instruction. In connection with this, Salom (2013) stated that faculty members in higher educational institutions should become research-conscious because it is an essential factor in effecting innovations. In addition, according to him, any change(s) in the structure of education, in school programs/projects/activities, and in approaches and techniques should be first subjected to research because it is only research that can provide the factual bases for their effectiveness or ineffectiveness. In other words, all educational activities for total development are based on research.

The dearth in research in Philippine Higher Education Institutions (HEIs) had driven the Commission on Higher Education (CHED) to provide policies and mandates that are largely geared towards the improvement of research productivity. The HEIs in the country responded in varied ways to the call for a stronger research orientation among the universities (Clemeña \& Acosta, 2007).

Universities have been operationally defined as follows: At least 30 full-time faculty members or $20 \%$ of all fulltime faculty, whichever is higher, are actively involved in research (CHED, 2014). It is also in this context that the function of faculty in higher education institutions has traditionally been trifocal, consisting of teaching, research and community service, and extension. This traditional trinity is expected to operate in relation to the specific goals and mission of the institution.

To respond to the policies and mandates of Commission on the Higher Education (CHED), Saint Mary's University through its Faculty Research Development Program, a scheme borne of the plans of the University Research Center (IDP Year 2013-2014) aimed to strengthen and enhance the research skills of faculty members so that eventually they will develop into home-grown full-time researchers in their fields of specialization. Research capability, on the other hand, is the facility or potential of individuals, organizations, and systems to undertake and disseminate effectively and efficiently high-quality research. It includes "institutional" consideration that covers the incentives, the economic, political and regulatory context and the resource base on which the context is built.

In the said capacitation, a series of training undertaken in the duration of four years, a faculty member was expected to evolve from apprenticeship to promoters. It was also a venue for a novice to learn and apply the basics of research, particularly for those whose only research experience was the writing of masterate or doctorate thesis. It also exposed them to the challenges of production, dissemination, publication, and the implementation of research results. By the end of the three-year period, it was expected that they would have imbibed the research culture and realized the importance of research not as additional but an integral function of a university faculty.

For some time, there has been a rarity in research productivity, punctuated only by the outputs of a few faculty members across schools. In time with the aggressive implementation of mechanisms $\mathrm{C}$ and $\mathrm{D}$ by the current administration, a big number of faculty got involved either individually or collaboratively. The URC has to address this yearly, to assure a steady number of researchers and researches involved and produced respectively.

Hence, URC conducted a seminar-workshop on research to empower the participants to become research proponents who will conduct research activities either individually or collaboratively within or across schools in the University. In the long run, this would be a stepping stone for the participants to develop into full-time researchers through a series of capacitation following three graduated research program tracks. It was also meant to involve them in research as advisers, panel members, or reviewers in their respective school research councils, and finally, to enable them to publish their researches in local or international refereed journals. This may also qualify them to disseminate in local, regional or international fora or to develop proposals for local, regional or national funding. 
Thus, this study aimed to assess the efficacy of the research faculty development seminar-workshop. This study evaluated the results of the training programs by determining whether the participants gained skills from the training on writing the first three chapters of the research paper using Saint Mary's University's standard format. These included Rationale/Background of the study (Chapter 1), Review of Related Literature and Studies (Chapter 2) and Research Methodology (Chapter 3) and putting the same into practice.

This study thus assessed the efficacy of the research faculty development program workshop in writing a full-blown research proposal.

Specifically, it answered the following questions:

a) What are the assessed pre-needs of the participants in the seminar-workshop on research capacitation in terms of the following:

1) Expectations in this research training activity;

2) Strengths and weaknesses as a researcher; and

3) The emphasis on the research process that they want?

b) What is the efficacy of the seminar-workshop in terms of:

1) Evaluation of outputs by the panel of evaluators

2) Evaluation results of the implementation of the delivery of the seminar-workshop

3) Evaluation of the attainment of the seminar objectives in terms of:

(a) General objectives of the seminar-workshop;

(b) Course sessions content and process; and

(c) Resource speakers.

c) Is there a significant difference between the scores in making research proposals when grouped according to (a) type of researcher; (b) educational and (c) research exposure?

d) Is there a significant difference between the evaluation of participants' research proposals between and across the three chapters of the research paper?

e) What are the most significant learning /insights trainees gained from the workshop?

\section{Conceptual Framework}

Constructivism is an epistemological view of knowledge acquisition emphasizing knowledge construction rather than knowledge transmission and the recording of information conveyed by others. The role of the learner is conceived as one of building and transforming knowledge (Applefield, Huber \& Moallem, 2001). Constructivism refers to the theory that human knowledge is constructed by individuals and within social communities and that the disciplines, or bodies of knowledge, are also human constructions (Phillips, 1995).

There are three types of constructivism: exogenous constructivism, endogenous constructivism and dialectical constructivism (Moshman, 1982). In exogenous constructivism or realism, the information processing conceptualizations of cognitive psychology emphasize the representation view of constructivism, calling attention to how an individual construct and elaborate schemata and networks of information based on the external realities of the environments they experience.

Endogenous constructivism or cognitive constructivism (Cobb, 1994; Moshman, 1982) focuses on individual constructions of knowledge. The emphasis is derived from Piagetian theory (Piaget 1977, 1970 as cited by Applefield, Huber \& Moallem, 2001), in which individual knowledge construction was stimulated by internal cognitive conflict as learners strive to resolve mental disequilibrium. Students may create their own knowledge, and advance it by revisions of existing understanding. This is done during individual or socially mediated discovery-oriented learning activities.

Dialectical constructivism or social constructivism (Brown, Collins, \& Duguid, 1989; Rogoff, 1990, as cited by Applefield, Huber \& Moallem, 2001) views the origin of knowledge construction as being the social intersection of people. These involve comparing, sharing, and even debating among learners and mentors. The social milieu of learning is bestowed on the center stage and learners both develop their own meanings and help others find meaning through this highly interactive process. There is a mutual knowledge built. This view is a direct reflection of Vygotsky's (1978) sociocultural theory of learning, which accentuates the supportive guidance of mentors as they enable the apprentice learner to achieve successively more complex skill, understanding, and ultimately independent competence.

In this study, the trainees were taught how to make a research proposal consisting of an introduction to the study, review of related literature and studies, and research methodology. Trainees had initial knowledge of research writing

Gurat, M., del Rosario, F. Y., Dizon, P. K., \& Saludarez, M. (2018). Assessment of research faculty development program efficacy in writing research proposals. International Research Journal of Management, IT and Social Sciences, 5(4), 1-17. https://doi.org/10.21744/irjmis.v5n4.238 
as well as experiences in writing research. They also had an exchange of ideas with other trainees. Hence, enlightened by the theory of constructivism, Figure 1 shows the research design paradigm patterned after the Input - Process Output Model to illustrate the relationships of the variables studied.

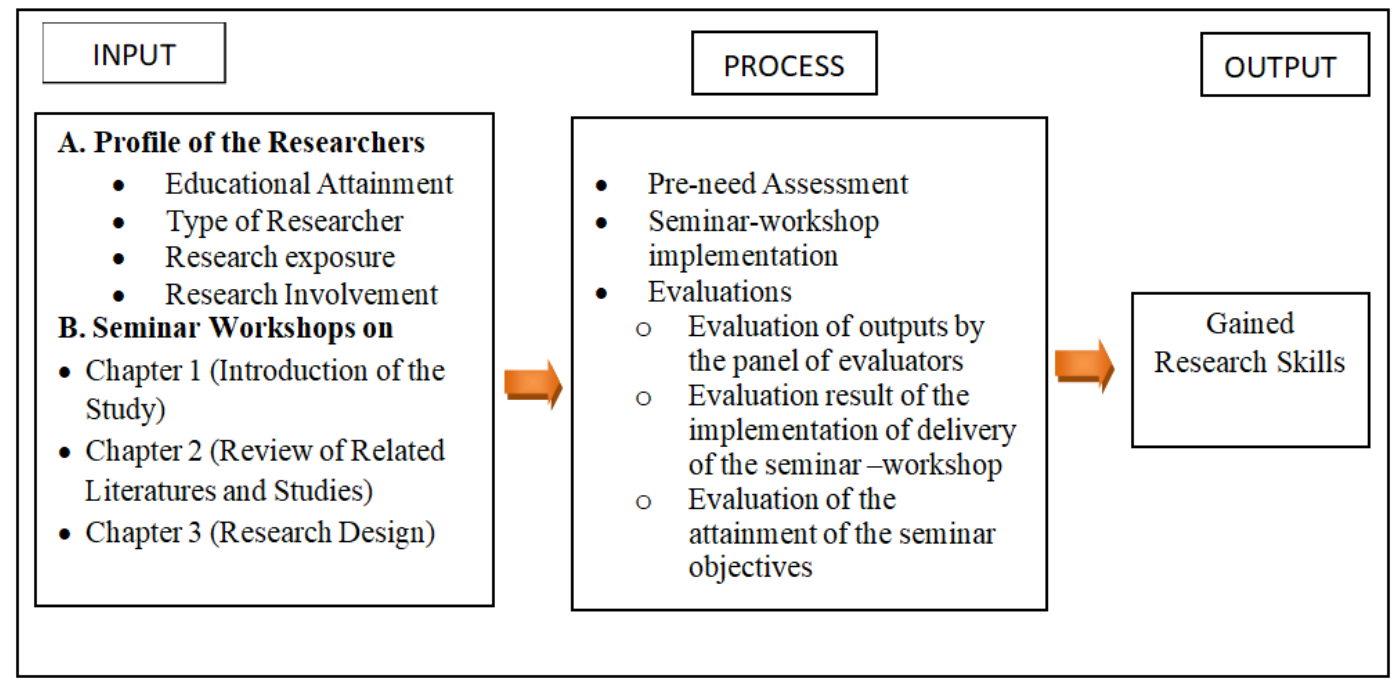

Figure 1. Research Design of the Study

The subjects of the study were all participants in the seminar-workshop. The inputs of the study were the lectures in the seminar-workshop. As mentioned, this included lectures on three chapters of research paper namely: the introduction of the study, review of related literature and studies, and research methodology. A needs assessment was administered to the selected participants before the conduct of the seminar-workshop. The seminar-workshop took place on October 27-31, 2014 and every Wednesday of the school year 2015-2016 as long as subjects and lecturers were available. Participants were asked to submit their research proposals consisting of the three chapters. The outputs of the subjects were evaluated. Hence, the output of this study was the gained research skills particularly in making a research proposal.

\section{Research Methods}

This study involved the quantitative type of research using the posttest-only control group experimental design since the subjects were evaluated after the intervention. This study was also evaluative since it determined whether the capacitation in the faculty research development program in developing Chapter I, Chapter II, and Chapter III of a research paper was effective. The assessment of the faculty development program will be a guide for future decisions both by the URC and the administration with regards research-related interventions or activities for faculty. It is the quantitative type of research because it considered the scores in the assessment of the effectiveness of the faculty research development program. It is also a descriptive-comparative type of research since the profile variables were compared in the assessment of gained skills of the researchers in writing a research proposal.

\section{Results and Analysis}

\subsection{Pre-need assessment of the participants in the seminar-workshop on research capacitation}

a) Expectations in the seminar-workshop on research capacitation 
Table 1

Frequency counts and percents on the expectations of the participants in the seminar-workshop on research capacitation

\begin{tabular}{lcc}
\hline \multicolumn{1}{c}{ Expectations } & Frequency & Percent \\
\hline To develop faculty members into full-time researchers through a series of capacitation & 11 & 52.4 \\
following three graduated research program tracks. & 3 \\
To integrate these would - be researchers as advisers, panel members, or reviewers in & 14.3 \\
their respective school research councils & 3 \\
To empower them to become research proponents who will conduct research activities & 14.3 \\
either individually or collaboratively within or across Schools & 3 \\
To enable to publish locally or international refereed journals/ to qualify to disseminate & 14.3 \\
in local, regional or international fora/ to develop proposals for local, regional or & \\
national funding. & 2 \\
Interest/Appreciation/confidence & 4 \\
Training Expectations & 2 \\
Assistance & 9.5 \\
(materials) & 19.0 \\
Speakers & 9.5 \\
\hline
\end{tabular}

As gleaned from Table 1, the majority of the participants expected that the seminar-workshop on research capacitation can develop faculty members into full-time researchers through a series of capacitation following three graduated research program tracks.

This is supported by the following responses from the participants of the seminar-workshop:

"To be capacitated with research skills" (P1)

"To improvelenhanced my knowledge and skills in research" (P6)

"To be capacitated with research skills, to develop more skills in research and to be expert quantitative and qualitative researcher" (P7)

"To develop my skills in writing research" (P6)

"To develop and understand the process of research and to be able to conduct research in the future that is of quality (P14)"

"Enhancement of our research skills"(P17)

"To learn how to conceptualize research and to learn and apply concepts and methods in conducting research" (P18)

"A thorough training in research rubrics that would not be in conflict with our other professional and personal commitments" (P21)

Said qualitative responses show that the participants were expecting to meet the objectives of the seminar-workshop.

b) Strengths as a researcher

Table 2

Frequency counts and percents of the strengths of the participants as a researcher

\begin{tabular}{lcc}
\hline Strengths & Frequency & Percent \\
\hline Topic & 1 & 4.8 \\
Chapter1/Conceptualizing & 5 & 23.8 \\
RRL & 5 & 23.8 \\
Data gathering & 4 & 19.0 \\
Advising/critiquing & 2 & 9.5 \\
Commitment & 1 & 4.8 \\
Interest & 3 & 14.3 \\
Reference & 1 & 4.8 \\
Writing the paper & 2 & 9.5 \\
Field-Related & 4 & 19.0 \\
\hline
\end{tabular}

Gurat, M., del Rosario, F. Y., Dizon, P. K., \& Saludarez, M. (2018). Assessment of research faculty development program efficacy in writing research proposals. International Research Journal of Management, IT and Social Sciences, 5(4), 1-17. https://doi.org/10.21744/irjmis.v5n4.238 
As shown in Table 2, most of the participants' strength is in doing Chapter 1 or conceptualizing research problem or to write a review of related literature and studies (23.8\%). However, this only represents almost one-fourth of the participants.

The strength in making chapter 1 or conceptualizing is supported by the following responses of the participants.

"Conceptualization of problem" (P8)

"Conceptualizing framework for research study"(P9)

"Conceptualization of quantitative researches" (P12)

"Making an introduction and conceptual framework" (P17)

The strength in making a review of the related literature was supported by the following responses of the participants.

"Gathering data from online sources" (P16)

"I am good in doing a review of the related literature" (P18)

"Gathering, collating and organizing RRL" (P17)

"Conducting a review of the related literature" (P3)

c) Weaknesses as a researcher

Table 3

Frequency counts and percents of the weaknesses of the participants as a researcher

\begin{tabular}{lcc}
\hline Weaknesses & Frequency & Percent \\
\hline Topic & 5 & 23.8 \\
Chapter1/Conceptualizing & 6 & 28.6 \\
RRL & 4 & 19.0 \\
Methodology & 7 & 33.3 \\
Data gathering & 4 & 19.0 \\
Analysis and interpretation & 8 & 38.1 \\
Writing the paper & 4 & 19.0 \\
Qualitative & 3 & 14.3 \\
SPSS & 7 & 33.3 \\
Conclusion & 1 & 4.8 \\
Format APA & 1 & 4.8 \\
Time management/ research process & 1 & 4.8 \\
\hline
\end{tabular}

Table 3 shows that most of the participants' weakness is analysis and interpretation (38.1\%) with a slight difference in methodology $(33.3 \%)$ or using SPSS $(33.3 \%)$.

The participants' weakness in analysis and interpretation is supported in their responses shown below:

"Data analyzes" (P4, P7)

"Analysis of data" (P13)

The weakness in methodology or using SPSS is also supported by the following responses below:

"Methodology" (P7, P9, P10)

"research methodology and statistics" (P17)

"Statistical treatment of data in science. IS there an existing statistical program in our research center which we can specifically use in treating or analyzing data in science?"(P20)

"Statistical and other modes of treating data". (P21)

"Research methodology and data analysis"(P12)

d) The emphasis on the research process the participants desired

Table 4

Frequency counts and percents on the emphasis in the research process that the participants desired

\begin{tabular}{lcc}
\hline Categories & Frequency & Percent \\
\hline Mechanics & 2 & 9.5 \\
\hline
\end{tabular}




\begin{tabular}{llc}
\hline \hline Conceptualization & 9 & 42.9 \\
RRL & 3 & 14.3 \\
Methodology & 9 & 42.9 \\
SPSS / quantitative & 7 & 33.3 \\
Qualitative & 6 & 28.6 \\
Writing & 2 & 9.5 \\
Others & 3 & 14.3 \\
\hline
\end{tabular}

Table 4 reveals that the emphasis in the research process that the participants desired was on conceptualization (42.9\%) or methodology (42.9\%).

Based on the pre-need assessment, the participants' answers revealed that although they claimed that they had strengths in some areas of doing research they also had their weaknesses.

The expectations of the participants that the seminar-workshop can develop them into full-time researchers through a series of capacitation following three graduated research program tracks, strengthened the need to conduct the seminar-workshop to address the weaknesses identified by the participants as well as to improve the strengths that they have in order to realize the objectives of the research capacitation activity.

\subsection{Assessment of the efficacy of the seminar-workshop}

a) Evaluation of outputs by the panel of evaluators

Table 5

Frequency Counts and Percents of the Evaluation of Output

\begin{tabular}{llclclclc}
\hline & & Chapter 1 & Chapter 2 & \multicolumn{2}{c}{ Chapter 3 } & \multicolumn{2}{c}{ Over all } \\
& $\mathrm{f}$ & $\%$ & $\mathrm{~F}$ & $\%$ & $\mathrm{f}$ & $\%$ & $\mathrm{f}$ & $\%$ \\
\hline Excellent & 9 & 36 & 11 & 44 & 6 & 24 & 7 & 28 \\
Very Good & 9 & 36 & 6 & 24 & 4 & 16 & 11 & 44 \\
Good & 0 & 0 & 1 & 4 & 8 & 32 & 0 & 0 \\
Fair & 0 & 0 & 0 & 0 & 0 & 0 & 0 & 0 \\
Poor & 7 & 28 & 7 & 28 & 7 & 28 & 7 & 28 \\
Total & 25 & 100 & 25 & 100 & 25 & 100 & 25 & 100 \\
Mean & 57.60 & & 58 & & 47.87 & & 54.80 & \\
SD & 37.66 & & 38.45 & & 33.35 & & 36.13 & \\
QD & Good & & Good & Good & & Good & \\
\hline
\end{tabular}

Legend: 0-19.49 (poor), 19.50-39.49 (fair), 39.50-59.49 (good), 59.50-79.49 (very good) and 79.50-100 (excellent)

Most of the participants obtained a rating of excellent or very good in writing chapter 1(36\%). Most of them had an excellent rating in writing chapter $2(44 \%)$ but had a rating of good in writing chapter $3(32 \%)$ and with an only slight difference with those who obtained a poor rating. Overall, most of the participants were rated very good in writing a research proposal. However, other participants had extreme results in their performance, where the same number of participants had an excellent rating and poor ratings $(28 \%)$.

On the average, the performance of the participants based on the evaluation of their outputs was good. This means that the knowledge and skills acquired by the participants in the seminar-workshop were satisfactory.

This was supported by the responses of the participants when asked, "what strengths have you acquired or developed? What weaknesses do you still perceive need to be addressed?"

The responses on the strengths included the following:

"How to critique the state of the problem and conceptual framework" $(P 1)$

"How to make a conceptual framework" (P5)

The responses of participants 1 and 5 revealed that their strength was making chapter 1 particularly in developing the conceptual framework and critiquing the statement of the problem. On the other hand, the following responses showed that the participants also improved their skills in chapter 2:

"I learned about the simulacrum in the review of related literature and enriched my knowledge about research". (P7)

Gurat, M., del Rosario, F. Y., Dizon, P. K., \& Saludarez, M. (2018). Assessment of research faculty development program efficacy in writing research proposals. International Research Journal of Management, IT and Social Sciences, 5(4), 1-17. https://doi.org/10.21744/irjmis.v5n4.238 
"Skills in developing/writing RRLs were enhanced "(P8)

"The strengths that I have acquired /developed in writing simulacrum" (P10)

The responses showed that participants 2, 7,8 and 10 emphasized that their strength acquired in the seminarworkshop was to write the review of related literature and using simulacrum. Moreover, some respondents also disclosed that they acquired or improved their knowledge and skills not only in one particular chapter but in all chapters involved in making research proposals. The following were responses showing that chapters 1 and two were improved:

"Writing of statement of the problem; conceptual framework and definition of terms" (P4)

"Identification of working title and use of simulacrum" (P6)

"All of it from title to related literature." (P2)

As mentioned, the result of their performance was only good. Evidence were also obtained from the participants by asking them their weaknesses even after the seminar-workshop. The following were the responses of the participants:

"Methodology especially in experimental designs" (P2)

The responses of the participants unveiled that they still had difficulty in writing methodology particularly experimental designs (P2). The methodology was never mentioned by the participants as their strength after the seminar-workshop. Participants 5 and 6 noted that they still had a problem in writing chapter 2 particularly in paraphrasing and using APA format.

"How to paraphrase and summarize, how to write the RRL and how to use the APA." (P5)

"Paraphrasing since we were not able to attend the lecture because we were required to assist during the enrollment."(P6)

Participant 7 revealed that he needed more knowledge in writing related literature and in writing a conceptual framework. The response of participant 1 is shown below:

"I need to learn more on RRL, APA and preparation of conceptual framework"(P7)

On the other hand, the identified weakness of participant 1 is more of critiquing papers and this entails better knowledge and skills in making research paper to come up with a valid and justifiable critique on the research paper. The answer of participant 1 is shown below:

"More immersion in critiquing of papers." (P1)

Based on the responses of the participants and the result of the evaluation of the panel of evaluators on their outputs in making full-blown research proposals, the participants had acquired good enough knowledge and skills in the seminar-workshop and by practice, the acquired knowledge and skills can be improved.

\section{b) The evaluation result of the implementation of the delivery of the seminar-workshop}

During the last day of the seminar-workshop, there were only eleven participants who attended the closing program. The result of their evaluation in the given survey questionnaire is shown in Table 13.

Table 6

Frequency counts and percents of the level of satisfaction in the seminar-workshop

\begin{tabular}{ccc}
\hline Level of Satisfaction & Frequency & Percent \\
\hline very satisfied & 2 & 18.2 \\
very much satisfied & 9 & 81.8 \\
Total & 11 & 100.0 \\
\hline
\end{tabular}

The level of satisfaction of the participants in the seminar-workshop is very much satisfied (81.8\%) or very satisfied $(18.2 \%)$.

One possible reason for all the participants not being very much satisfied was the schedule of the activity as reflected in the answer of one of the participants who said, "would it be possible not to schedule the seminar on clearance periods and submission of grades?"

Another reason was time management. Participant 7 said that "the time should be followed". Participant 8 supported this by saying, "time frame during presentations was not uniformly followed. Presenters should be made aware of their time limit and facilitators should not be so kind and accommodate."

Hence, the majority of the participants rated that they were very much satisfied, however, schedule and time management were identified as loopholes of the seminar-workshop. 
c) Evaluation of the attainment of the seminar objectives

Table 7

Frequency counts and percents of the attainment of the seminar objectives

\begin{tabular}{|c|c|c|c|c|c|c|c|c|}
\hline \multirow[t]{2}{*}{ Attainment } & \multicolumn{2}{|c|}{$\begin{array}{c}\text { General } \\
\text { Objectives }\end{array}$} & \multicolumn{2}{|c|}{$\begin{array}{c}\text { Specific } \\
\text { Objectives } \\
\text { during Lecture }\end{array}$} & \multicolumn{2}{|c|}{$\begin{array}{c}\text { Specific Objectives } \\
\text { during } \\
\text { workshop }\end{array}$} & \multicolumn{2}{|c|}{$\begin{array}{c}\text { The effectiveness of } \\
\text { Speaker in attaining } \\
\text { objectives }\end{array}$} \\
\hline & $\mathrm{f}$ & $\%$ & $\mathrm{f}$ & $\%$ & $\mathrm{f}$ & $\%$ & $\mathrm{f}$ & $\%$ \\
\hline somewhat attained & 0 & 0 & 0 & 0 & 1 & 9.1 & 0 & 0 \\
\hline mostly attained & 1 & 10.0 & 1 & 9.1 & 1 & 9.1 & 0 & 0 \\
\hline fully attained & 9 & 90.0 & 10 & 90.9 & 8 & 72.7 & 10 & 100 \\
\hline Total & 10 & 100.0 & 11 & 100.0 & 10 & 90.9 & 10 & 100 \\
\hline
\end{tabular}

Based on Table 7, the majority of the participants fully attained the general objectives of the seminar-workshop (90\%), specific objectives during lecture $(90.9 \%)$ and workshops $(72.7 \%)$. They also rated the effectiveness of the speakers in attaining the objectives as fully attained (100\%).

Table 8 shows the median and qualitative descriptive in the general and specific objects of the seminar-workshop.

Table 8

Median and qualitative description of the attainment of the seminar objectives

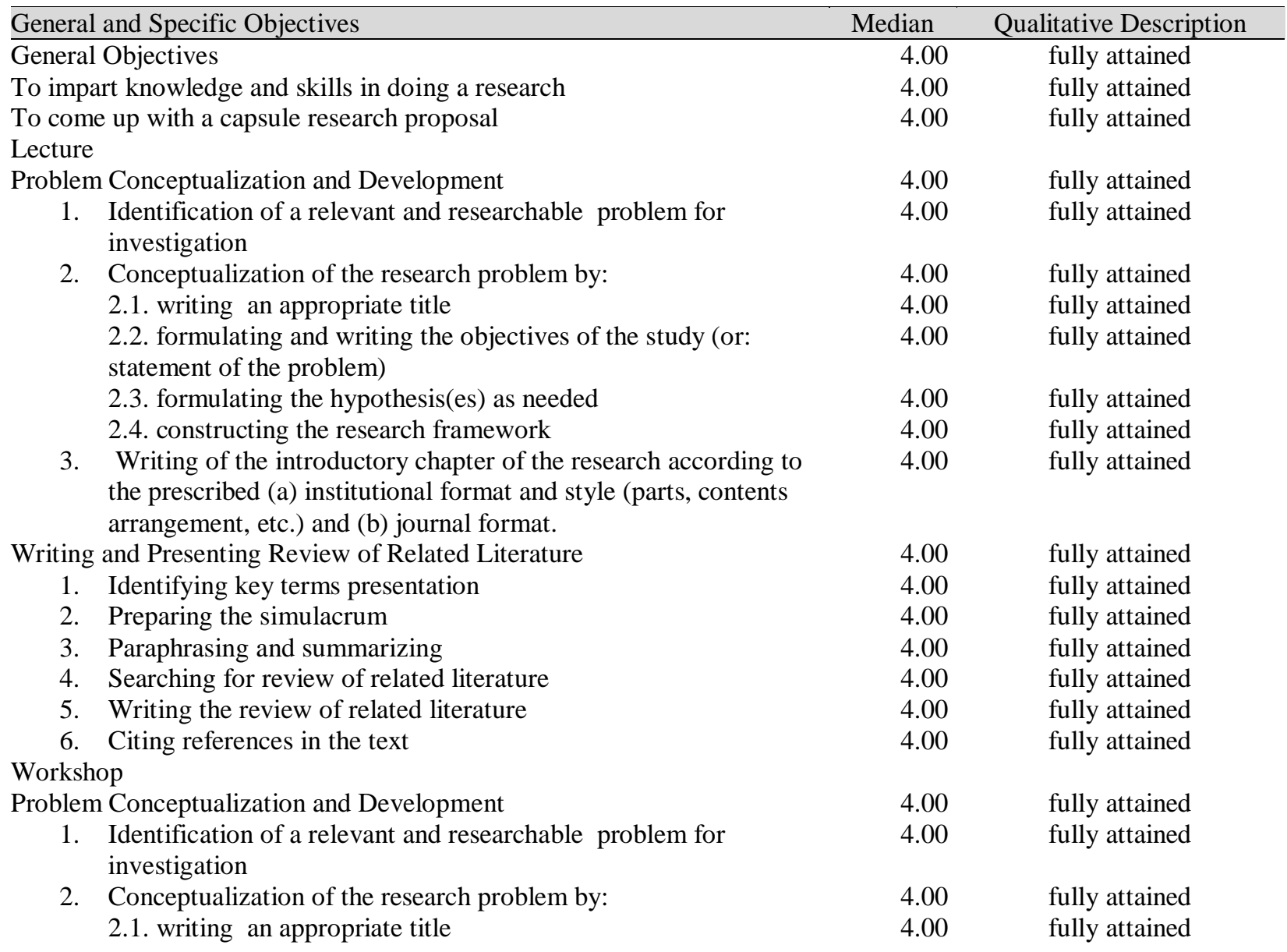

Gurat, M., del Rosario, F. Y., Dizon, P. K., \& Saludarez, M. (2018). Assessment of research faculty development program efficacy in writing research proposals. International Research Journal of Management, IT and Social Sciences, 5(4), 1-17. https://doi.org/10.21744/irjmis.v5n4.238 


\begin{tabular}{|c|c|c|}
\hline General and Specific Objectives & Median & Qualitative Description \\
\hline 2.2. formulating and writing the Objectives of the Study (or: & 4.00 & fully attained \\
\hline Statement of the Problem) & & \\
\hline 2.3. formulating the hypothesis(es) as needed & 4.00 & fully attained \\
\hline 2.4. constructing the Research Framework & 4.00 & fully attained \\
\hline $\begin{array}{l}\text { 3. Writing of the introductory chapter of the research according to } \\
\text { the prescribed (a) institutional format and style (parts, contents } \\
\text { arrangement, etc.) and (b) journal format. }\end{array}$ & 4.00 & fully attained \\
\hline Writing and Presenting Review of Related Literature & 4.00 & fully attained \\
\hline 1. Identifying key terms presentation & 4.00 & fully attained \\
\hline 2. Preparing the simulacrum & 4.00 & fully attained \\
\hline 3. Paraphrasing and summarizing & 4.00 & fully attained \\
\hline 4. Searching for review of related literature & 4.00 & fully attained \\
\hline 5. Writing the review of related literature & 4.00 & fully attained \\
\hline 6. Citing references in the text & 4.00 & fully attained \\
\hline Resource Speakers & 4.00 & fully attained \\
\hline
\end{tabular}

As gleaned from Table 8, the general and specific objectives in both lecture and works, as well as the effectiveness of the resource speakers in attaining the objectives, was fully attained.

This was supported by the response of participant 10 who stated that "All the objectives were met" and participant 8 who said, "All objectives were satisfactorily met".

However, the result also revealed that not all rated it as fully attained and this can be inferred from the response of participant 9 who suggested that, "hand-outs or photocopies of the lectures should be given at the start of the lecture". Participant 1 also suggested having a seminar for advisers/panelists on how to critic a thesis or research paper as shown in her answer below:

"Can we have a seminar for advisers/panelists on how to critic a thesis/research paper?"

In terms of the specific objectives through course sessions and process, the same comment supports the result of the findings from participants 2 and 8 stating that "All the objectives were met". On the other hand, a comment from participant 1 is, "more time is needed to write RRL". Moreover, participant 10 said that "the writing of the introductory chapter of the research according to prescribed institutional format and style and journal format should be discussed in more detailed manner."

In terms of the effectiveness of the resource speakers in attaining the objectives of the seminars, the following were the comments from the participants:

"Congratulations to the speakers! We learned much. Carry on!" (P1)

"Excellent speakers, receptive and queries and accommodating even outside of workshop" (P8)

"All speakers were good in discussing their topics" (P10)

A suggestion from participant 2 stated that "please invite also speakers that will focus on experimental researches. Thank you!"

Based on the result of the survey questionnaire together with the comments and suggestions from the participants, the organizers successfully conducted the seminar-workshop because it fully attained the objectives of the activity. However, some suggestions for the improvement included a seminar for advisers/panel members in critiquing research papers, more detailed discussion on research formats, more time in writing review of related literature and discussion on experimental researches by another speaker.

3.3 Significant difference between the scores in making research proposals when grouped according to $(a)$ type of researcher; (b) educational attainment and (c) research exposure

a) A significant difference between the scores in making research proposals when grouped according to the type of the researcher 
Table 9

Mann-Whitney U test result on the significant difference between the scores in making research proposals when grouped according to the type of the researcher

\begin{tabular}{|c|c|c|c|c|c|c|}
\hline & Type_of_researcher & $\mathrm{N}$ & Mean Rank & Sum of Ranks & $\begin{array}{c}\text { Mann- } \\
\text { Whitney U }\end{array}$ & $\begin{array}{l}\text { Exact Sig. [2*(1- } \\
\quad \text { tailed Sig.)] }\end{array}$ \\
\hline \multirow{3}{*}{ Chapter1_Scores } & Seasoned & 16 & 12.81 & 205.00 & 69.000 & .890 \\
\hline & Neophyte & 9 & 13.33 & 120.00 & & \\
\hline & Total & 25 & & & & \\
\hline \multirow{3}{*}{ Chapter2_scores } & Seasoned & 16 & 12.06 & 193.00 & 57.000 & .419 \\
\hline & Neophyte & 9 & 14.67 & 132.00 & & \\
\hline & Total & 25 & & & & \\
\hline \multirow{3}{*}{ Chapter3_Scores } & Seasoned & 16 & 11.72 & 187.50 & 51.500 & .251 \\
\hline & Neophyte & 9 & 15.28 & 137.50 & & \\
\hline & Total & 25 & & & & \\
\hline \multirow{3}{*}{ Total Scores } & Seasoned & 16 & 12.25 & 196.00 & 60.000 & .522 \\
\hline & Neophyte & 9 & 14.33 & 129.00 & & \\
\hline & Total & 25 & & & & \\
\hline
\end{tabular}

As gleaned from Table 9, the mean ranks result of neophyte researchers is consistently higher than the mean ranks of the scores of seasoned researchers in all chapters and in overall. This means that the evaluations of the outputs of neophyte researchers are higher than the evaluations of the outputs of the seasoned researchers. However, MannWhitney U test result shows that there is no significant difference between the scores in making research proposals when grouped according to the type of researcher. The result reveals that the knowledge and skills of neophyte researchers in making research proposals are the same as the seasoned researchers after the seminar-workshop. The result suggests that the seminar-workshop attained its objective to strengthen and enhance the research skills of faculty members. This also means that neophyte researchers can make research proposals even without the help of seasoned researchers.

b) A significant difference between the scores in making research proposals when grouped according to educational attainment

Table 10

Mann-Whitney U test result on the significant difference between the scores in making research proposals when grouped according to educational attainment

\begin{tabular}{|c|c|c|c|c|c|c|}
\hline & Educational attainment & $\mathrm{N}$ & Mean Rank & Sum of Ranks & $\begin{array}{c}\text { Mann- } \\
\text { Whitney U }\end{array}$ & $\begin{array}{l}\text { Exact Sig. [2*(1- } \\
\text { tailed Sig.)] }\end{array}$ \\
\hline \multirow{3}{*}{ Chapter1_Scores } & $\begin{array}{l}\text { on-going } \\
\text { masters/master's } \\
\text { finished }\end{array}$ & 14 & 10.82 & 151.50 & 46.500 & .095 \\
\hline & $\begin{array}{l}\text { on-going } \\
\text { doctorate/finished } \\
\text { doctorate }\end{array}$ & 11 & 15.77 & 173.50 & \multirow{5}{*}{35.000} & \multirow{5}{*}{$.021 *$} \\
\hline & Total & 25 & & & & \\
\hline \multirow{3}{*}{ Chapter2_scores } & $\begin{array}{l}\text { on-going } \\
\text { masters/master's } \\
\text { finished }\end{array}$ & 14 & 10.00 & 140.00 & & \\
\hline & $\begin{array}{l}\text { on-going } \\
\text { doctorate/finished } \\
\text { doctorate }\end{array}$ & 11 & 16.82 & 185.00 & & \\
\hline & Total & 25 & & & & \\
\hline
\end{tabular}

Gurat, M., del Rosario, F. Y., Dizon, P. K., \& Saludarez, M. (2018). Assessment of research faculty development program efficacy in writing research proposals. International Research Journal of Management, IT and Social Sciences, 5(4), 1-17. https://doi.org/10.21744/irjmis.v5n4.238 


\begin{tabular}{|c|c|c|c|c|c|c|}
\hline \multirow{3}{*}{ Chapter3_Scores } & $\begin{array}{l}\text { on-going } \\
\text { masters/master's }\end{array}$ & 14 & 10.29 & 144.00 & \multirow[t]{2}{*}{39.000} & \multirow[t]{6}{*}{$.038^{*}$} \\
\hline & $\begin{array}{l}\text { finished } \\
\text { on-going } \\
\text { doctorate/finished } \\
\text { doctorate }\end{array}$ & 11 & 16.45 & 181.00 & & \\
\hline & Total & 25 & & & \multirow{4}{*}{37.000} & \\
\hline \multirow{3}{*}{ Total Scores } & $\begin{array}{l}\text { on-going } \\
\text { masters/master's } \\
\text { finished }\end{array}$ & 14 & 10.14 & 142.00 & & \\
\hline & $\begin{array}{l}\text { on-going } \\
\text { doctorate/finished } \\
\text { doctorate }\end{array}$ & 11 & 16.64 & 183.00 & & \\
\hline & Total & 25 & & & & \\
\hline
\end{tabular}

*significant at 0.05 level **significant at 0.01 level

Table 10 shows that participants with an on-going doctoral degree or had finished doctoral degree had higher mean ranks in chapter 1 , chapter 2 , chapter 3 and in total score compared with participants with an on-going master degree or had finished master's degree. Moreover, inferential statistics result revealed that significant difference exists in all chapters in making research proposals and in their total score except in chapter 1. This means that participants who finished their doctoral degree or on-going doctoral degree make better research proposals as output in the seminarworkshop.

One possible reason is the research orientation received in their doctorate classes since graduate studies are research-based instructions.

c) A significant difference between the scores in making research proposals when grouped according to research exposure

Table 11

Mann-Whitney U test result on the significant difference between the scores in making research proposals when grouped according to research exposure

\begin{tabular}{llrrrrr}
\hline & Research exposure & $\mathrm{N}$ & Mean Rank & Sum of Ranks & $\begin{array}{c}\text { Mann- } \\
\text { Whitney U }\end{array}$ & $\begin{array}{c}\text { Exact Sig. [2*(1- } \\
\text { tailed Sig.) }\end{array}$ \\
\hline \multirow{3}{*}{ Chapter1_Scores } & lead researcher & 9 & 13.33 & 120.00 & 69.000 & .890 \\
& Collaborator & 16 & 12.81 & 205.00 & & \\
& Total & 25 & & & & .419 \\
& lead researcher & 9 & 14.67 & 132.00 & 57.000 & .251 \\
Chapter2_scores & Collaborator & 16 & 12.06 & 193.00 & & \\
& Total & 25 & & & & \\
& lead researcher & 9 & 15.28 & 137.50 & 51.500 & .522 \\
Chapter3_Scores & Collaborator & 16 & 11.72 & 187.50 & & \\
& Total & 25 & & & & \\
Total Scores & lead researcher & 9 & 14.33 & 129.00 & 60.000 & \\
& Collaborator & 16 & 12.25 & 196.00 & & \\
Total & 25 & & & & &
\end{tabular}

As shown in Table 11, participants who are exposed as lead researchers had higher mean ranks than those who were exposed as collaborators in all chapters and even in total scores. This means that the evaluation of the outputs of participants exposed as lead researchers was higher than those exposed as collaborators. This suggests that the participants exposed as lead researchers were more capable of making quality research papers because of their experiences as lead researchers. However, Mann-Whitney U test result revealed that there was no significant difference 
in the scores when grouped by research exposure. This means that the quality of the research proposals made by participants exposed as lead or collaborators was the same.

3.4 Significant difference between the evaluation of participants' research proposals between and across the three chapters of a research paper

Table 12

Friedman test result on the significant difference between the scores in making research proposals across the three chapters of the research paper

\begin{tabular}{|c|c|c|c|c|}
\hline & Mean Rank & Chi-Square & df & Asymp. Sig. \\
\hline Chapter1_Scores & 2.70 & 31.803 & 2 & $.000 * *$ \\
\hline Chapter2_scores & 1.94 & & & \\
\hline Chapter3_Scores & 1.36 & & & \\
\hline
\end{tabular}

The significant difference between and across the scores of the participants in each chapter was also tested using Friedman test. The score of the participants in chapter 1 was higher compared to chapter 2 or chapter 3 . Scores in chapter 2 were higher compared with chapter 1 based on their mean ranks. Furthermore, a significant difference exists. Figure 2 shows the result of pairwise comparison between mean ranks of scores in each chapter.

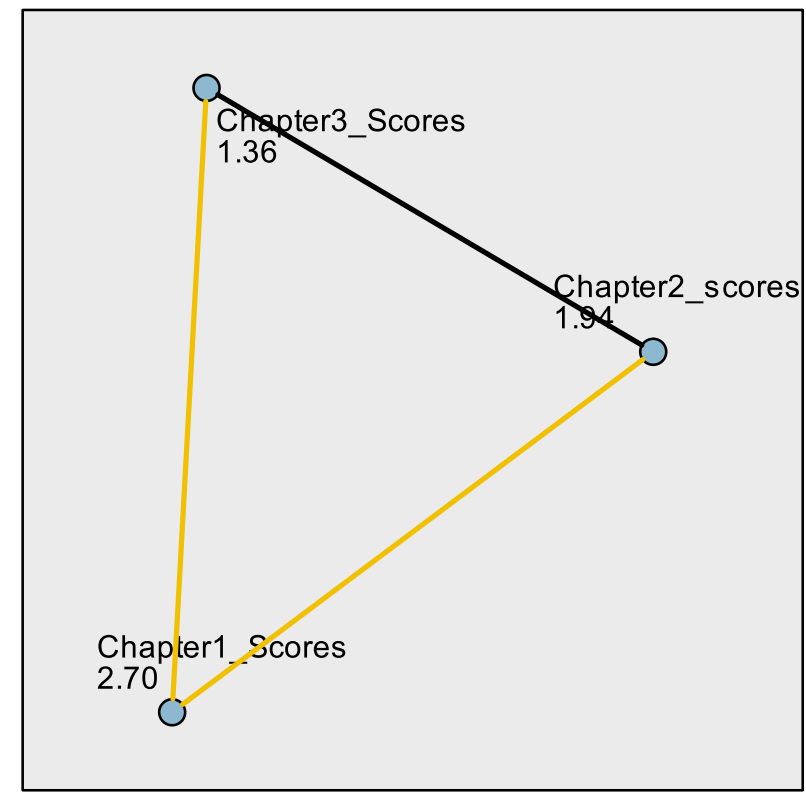

Each node shows the sample average rank.

Legend: $\square$ significant difference exist

Figure 2. Pairwise Comparison

The figure shows that there is a significant difference between the mean rank of the scores in making research proposals in chapter 1 and 3, and chapter 1 and chapter 2 . However, there is no significant difference in the mean ranks in the scores in chapter 2 and chapter 3 . This also indicates that the scores in making chapter 1 are significantly higher compared with mean ranks in making chapter 2 or chapter 3 . This means that the knowledge and skills in making research proposals as acquired by the participants are better in writing chapter 1 . However, the skills in writing chapter 2 and chapter 3 are the same.

Gurat, M., del Rosario, F. Y., Dizon, P. K., \& Saludarez, M. (2018). Assessment of research faculty development program efficacy in writing research proposals. International Research Journal of Management, IT and Social Sciences, 5(4), 1-17. https://doi.org/10.21744/irjmis.v5n4.238 
3.5 Most Significant Learning/Insights Gained in the Workshop

Table 13

Responses of participants on the most significant learning/insights gained in the workshop

\begin{tabular}{|c|c|c|}
\hline Respondent & & Responses \\
\hline 1 & $\begin{array}{l}1 . \\
2 . \\
3 .\end{array}$ & $\begin{array}{l}\text { The title, statement of the problem and conceptual framework are very important in } \\
\text { critiquing a paper. } \\
\text { The simulacrum is a great help in writing the RRL. } \\
\text { The new trends in writing research are indeed important updates/information in the field of } \\
\text { research. }\end{array}$ \\
\hline 2 & $\begin{array}{l}1 . \\
2 .\end{array}$ & $\begin{array}{l}\text { Conceptual designs } \\
\text { Related literature particularly in using simulacrum development and APA format }\end{array}$ \\
\hline 3 & $\begin{array}{l}1 . \\
2 .\end{array}$ & $\begin{array}{l}\text { Timely, helpful and systematic } \\
\text { Lectures very systematically and clearly presented. Congratulations to the research center } \\
\text { family for a job well done. For a noble purpose, we salute your commitment and support. } \\
\text { God bless. }\end{array}$ \\
\hline 5 & $\begin{array}{l}1 . \\
2 .\end{array}$ & $\begin{array}{l}\text { How to write the RRL } \\
\text { how to make a conceptual framework on how to paraphrase and summarize }\end{array}$ \\
\hline 6 & & $\begin{array}{l}\text { This activity motivated me to do more researches and become a lead researcher (hopefully } \\
\text { next school year). } \\
\text { It unlocks some of my difficulties in conducting research }\end{array}$ \\
\hline 7 & $\begin{array}{l}1 . \\
2 . \\
3 .\end{array}$ & $\begin{array}{l}\text { Simulacrum } \\
\text { conceptual and analytical framework } \\
\text { definition of terms }\end{array}$ \\
\hline 8 & & $\begin{array}{l}\text { Research is possible and attainable. } \\
\text { I am more equipped to assist my students in their thesis work. }\end{array}$ \\
\hline 10 & 1. & Writing the related literature through a simulacrum \\
\hline
\end{tabular}

Based on the responses of the participants, the most significant learnings in chapter 1 were the following: writing the title, statement of the problem, conceptual and analytical framework. In chapter 2, the participants identified simulacrum and APA format in writing review of related literature. They also mentioned paraphrasing and summarizing.

Moreover, the most significant insights of the participants were: The new trends in writing research are indeed important updates/information in the field of research. This activity motivated them to do more researches and become a lead researcher (hopefully next school year). It unlocked some of their difficulties in conducting research. They also realized that research is possible and attainable. With these, they also believe that they are more equipped to assist students in their thesis work.

Furthermore, they also commented that the seminar-workshop was timely, helpful and systematic. They mentioned that lectures were very systematically and clearly presented and they congratulated the Research Center family for a job well done, for a noble purpose, for commitment and support.

\section{Conclusion}

The research faculty development program workshop in writing research proposal was efficient in that:

a) The expectation of the participants was to be developed into full-time researchers through a series of capacitation following three graduated research program tracks. Participants have both strengths and weaknesses in making a research paper.

b) The expectations of the participants were met. The average evaluation of output by a panel of evaluators resulted to good in all chapters of full-blown research proposals and in overall. The implementation of the delivery resulted in "very much satisfied" and the attainment of objectives was "fully attained".

c) The knowledge and skills of neophyte researchers in making research proposals are the same as the seasoned researchers after the seminar-workshop. Hence, the seminar-workshop attained its objective to strengthen and enhance the research skills of faculty members. This also means that neophyte researchers can make research 
proposals even without the help of seasoned researchers. Moreover, the quality of the research proposals made by participants exposed as lead or collaborators was the same. The participants who finished their doctoral degree or on-going in doctoral degree made better research proposals as output in the seminar-workshop, one possible reason of which was the research orientation they received in their doctorate classes since graduate studies are research-based instruction.

d) The knowledge and skills in making research proposals as acquired by the participants were better in writing chapter 1 . However, the skills in writing chapter 2 and chapter 3 were the same.

e) The most significant learnings were in writing chapters 1 and 2 only. The most significant insight was their realization of what the seminar-workshop did to them in terms of equipping them with more knowledge and skills to make researches which in turn will enable them to help their students.

Conflict of interest statement and funding sources

The author(s) have no competing interest. The study was conducted under the auspices of Saint Mary's University.

Statement of authorship

The author(s) have a responsibility for the conception and design of the study. The author(s) have approved the final article.

Acknowledgments

The authors wish to thank Saint Mary's University for the support extended to the University Research Center for the series of capacitation conducted for faculty and from whom the data for this research had been culled.

Gurat, M., del Rosario, F. Y., Dizon, P. K., \& Saludarez, M. (2018). Assessment of research faculty development program efficacy in writing research proposals. International Research Journal of Management, IT and Social Sciences, 5(4), 1-17. https://doi.org/10.21744/irjmis.v5n4.238 


\section{References}

AlYahya, M. S., \& Norsiah, M. (2013). Evaluation of effectiveness of training and development: The Kirkpatrick model. Asian Journal of Business and Management Sciences, 2(11), 14-24.

Applefield, J. M., Huber, R., \& Moallem, M. (2000). Constructivism in theory and practice: Toward a better understanding. The High School Journal, 84(2), 35-53.

Boyer, E. L. (1998). The Boyer commission on educating undergraduates in the research university, reinventing undergraduate education: A blueprint for America's research universities. Stony Brook, NY, 46.

Brew, A., \& Jewell, E. (2012). Enhancing quality learning through experiences of research-based learning: Implications for academic development. International Journal for Academic Development, 17(1), 47-58.

Cobb, P. (1994). Constructivism in mathematics and science education. Educational Researcher, 23, 4-4.

Deakin, M. (2006). Research led teaching: a review of two initiatives in valuing the link between teaching and research. Journal for Education in the Built Environment, 1(1), 73-93.

Delgado, G. R. E., Meza, A. K. T., Chávez, S. A. R., \& Murillo, G. S. A. (2018). Demands of People with Disabilities and Empowerment of Resilient Strategies. International Research Journal of Management, IT and Social Sciences (IRJMIS), 5(1), 45-54.

Felder, R. M., \& Brent, R. (2010). The National Effective Teaching Institute: Assessment of impact and implications for faculty development. Journal of Engineering Education, 99(2), 121-134.

Gibbs, G., \& Jenkins, A. (2014). Teaching large classes in higher education: How to maintain quality with reduced resources. Routledge.

Good, C. V. and Scales, D.E. (1972). Methods of research. Educational, psychological, sociological. Manila: Appleton- Century- Crafts, Inc.

Hamrick, F. A., \& Klein, K. (2015). Trends and milestones affecting student affairs practice. New Directions for Student Services, 2015(151), 15-25.

Hine, G. S., \& Lavery, S. D. (2014). The importance of action research in teacher education programs: Three testimonies.

Jenkins, A. \& Healey, M. (2005) Institutional Strategies to link teaching and research. Higher Education Academy, York.

Meza, A. K. T., Aguayo, M. D. Z., Cevallos, M. G. O., \& Zambrano, P. F. R. (2018). Estimation of Resilience in University Students. International Research Journal of Management, IT and Social Sciences (IRJMIS), 5(1), 1624.

Meza, A. K. T., Freyre, J. R. A., Cevallos, M. G. O., \& Pico, M. J. M. (2018). Autonomy, Good Humor and Support Networks, Potential of Community Resilience Intervention in People Victims of the Earthquake in the Calderón Parish. International Research Journal of Management, IT and Social Sciences (IRJMIS), 5(1), 1-8.

Moshman, D. (1982). Exogenous, endogenous, and dialectical constructivism. Developmental review, 2(4), 371-384.

Phillips, D. C. (1995). The good, the bad, and the ugly: The many faces of constructivism. Educational researcher, 24(7), 5-12.

Phillips, D. C. (1997). How, why, what, when, and where: Perspectives on constructivism in psychology and education. Issues in Education, 3(2), 151-194.

Rajasekar, J., \& Khan, S. A. (2013). Training and development function in Omani public sector organizations: A critical evaluation. The Journal of Applied Business and Economics, 14(2), 37.

Rosen, J. B., Mangasarian, O. L., \& Ritter, K. (Eds.). (2014). Nonlinear Programming: Proceedings of a Symposium Conducted by the Mathematics Research Center, the University of Wisconsin, Madison, May 4-6, 1970 (No. 25). Elsevier.

Salazar-Clemeña, R. M., \& Almonte-Acosta, S. A. (2007, September). Developing research culture in Philippine higher education institutions: Perspectives of university faculty. In regional seminar "Competition, cooperation and change in the academic profession: Shaping higher education's contribution to knowledge and research." Hangzhou, China (pp. 1-13).

Salom, M. (2013). Research capability of the faculty members of DMMMSU Mid La Union Campus. International Scientific Research Journal 5(2): 45-55. ISSN 2094-1749

Tahilramani, R. (2013). The Influence of Organizational Culture on Training Effectiveness. ASM's international EJournal of ongoing Research in management andIT.

Undurthy, L. N., \& Peri, S. (2007). Developing teachers as researchers: A teacher preparation endeavor.

Unite for Sight (2015). Module 6: The importance of research. (Internet article). Retrieved from http://www.uniteforsight.org/research-methodology/module6 


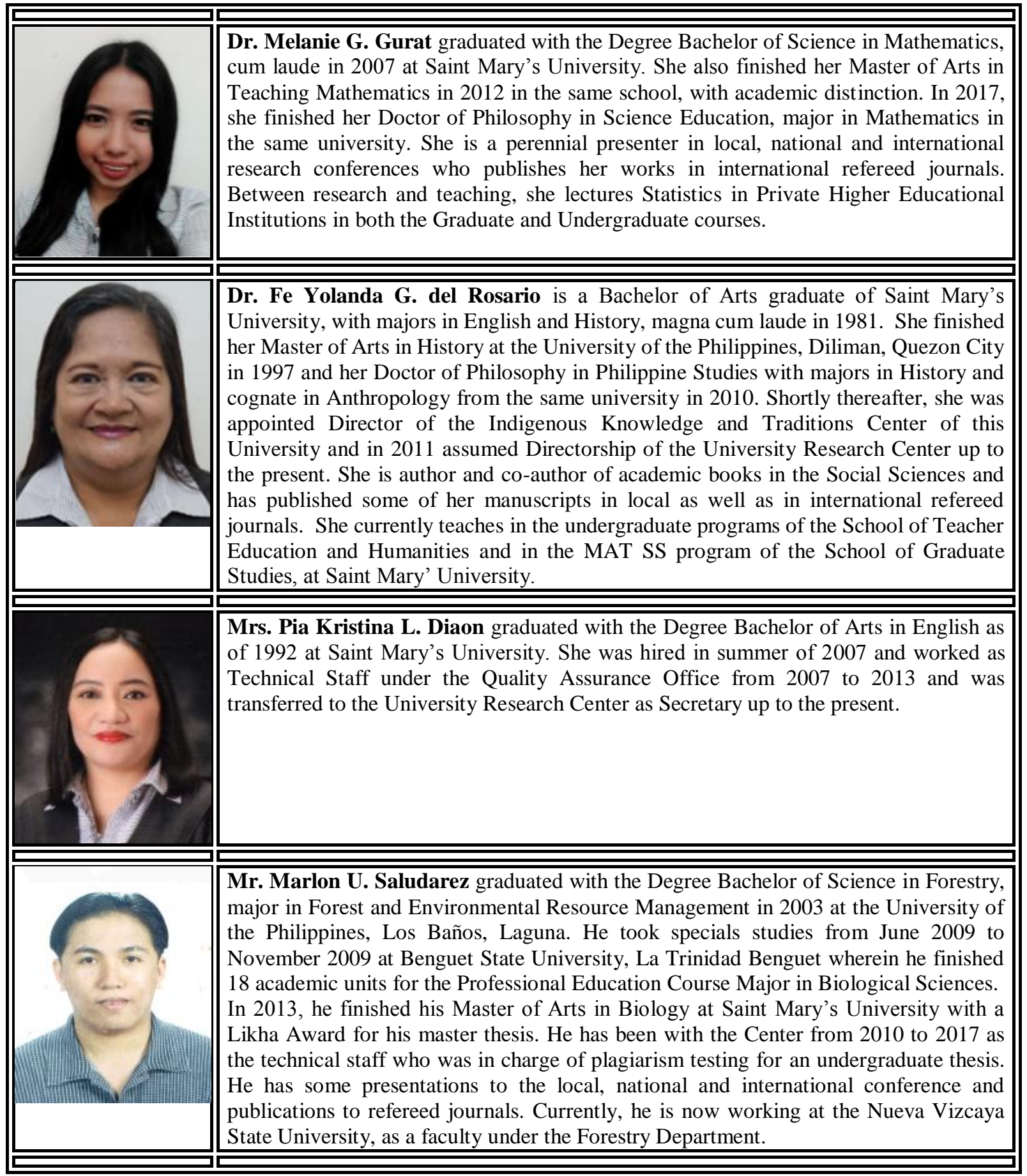

Gurat, M., del Rosario, F. Y., Dizon, P. K., \& Saludarez, M. (2018). Assessment of research faculty development program efficacy in writing research proposals. International Research Journal of Management, IT and Social Sciences, 5(4), 1-17. https://doi.org/10.21744/irjmis.v5n4.238 